\title{
FACTORS INFLUENCING FINANCIAL RISK TOLERANCE: A REVIEW
}

\author{
Mubarokah Bunyamin ${ }^{1, *}$, Norwazli Abdul Wahab1 \\ ${ }^{1}$ Faculty of Industrial Management, Universiti Malaysia Pahang, 26600 Pahang, Malaysia.
}

\begin{abstract}
High financial risk tolerance level encourages investors' participation in financial market. Thus, this can elevate their capabilities to achieve their financial goals and support national economic growth and well-being. This paper aims to investigate the factors affecting financial risk tolerance from studies around the globe. A comprehensive review of financial risk tolerance is carried out with a particular attention on factors that affects financial risk tolerance on financial decisions. This study indicates that financial risk tolerance can be explained by demographic profiles, psychology, social, geographical differences, and financial capability factors. These findings will be useful to professionals, technologists, and financial institutions to identify potential investors based on the indicators concluded with the suggestion on financial technology (FinTech) utilisation. Hence, this will encourage participation in Malaysian financial market during global health crisis and reach economic well-being towards industrial revolution 4.0 (IR 4.0).
\end{abstract}

\author{
ARTICLE HISTORY \\ Received: 30-7-2021 \\ Revised: 21-8-2021 \\ Accepted: 6-11-2021

\section{KEYWORDS} \\ Financial risk tolerance; \\ Financial decision; \\ Investment
}

\section{INTRODUCTION}

Financial risk tolerance (FRT) can be explained by the amount of risk a person is willing to take when making a financial decision or investment (Ferreira \& Dickason, 2018). Risk tolerance also is the measurement usually considered by financial institutions when profiling the investors' intentions towards short-term and long-term investments (Mankuroane, 2021). However, prior research studies paid less attention to a comprehensive investigation that reviews research articles on factors that give impacts on FRT. Thus, this study aims to fill the gap by investigating factors that affect FRT from around the world. To ensure relevancy, this study reviews studies within five recent years.

Most findings from previous studies show that men are more risk-tolerant than women. For instance, a study by Bannier and Neubert (2016) stated that higher risk tolerance relates positively to both standard and sophisticated investments for men, but only to standard investments for women. However, there is no relation between risk tolerance with women's sophisticated investments. Such conclusion is expected as men are the main breadwinners of households. Their participation in financial markets is one of the ways to multiply their incomes.

In order to encourage investors' participation in the financial markets, FRT is a significant aspect to take into account. The significance of FRT is emphasised by the managing director of United Overseas Bank Malaysia Berhad (UOB Malaysia) and country head of personal financial services, Ronnie Lim. Amid coronavirus (Covid-19) pandemic outbreak in Malaysia since January 2020, he stressed in New Straits Times (2021) that higher risk tolerance in assets investment is crucial to elevate investors' participation in market opportunities during financial markets volatile performance due to pandemic. Ronnie Lim believes that investors' continuous participation in market opportunities is important to ensure they achieve their long-term financial goals despite pandemic challenges. By effectively managing investment risks investors are taking, they will build resiliency into their portfolios. This resiliency would be the anchor decision point to sustain their investments, instead of being distracted by market volatility during the pandemic.

In that sense, it is believed that decisions related to investment participation have implications on investors' financial and overall well-being. Thus, it is important to have a financially high-risk-tolerant population for individuals' well-being as well as national economic well-being. This is because financially high-risk-tolerant investors are believed to encourage participation in more suitable investment products that match their financial goals. With consumer protection suitably applied, their participation in the financial market will benefit national economic growth and well-being. Therefore in this study, factors influencing FRT are investigated from studies in different countries.

In this study, there is an underpinning theory that explains FRT and its association with financial decision-making. According to Bandura and Walters (1977) in social learning theory, as social entities, people are believed to learn from observation of the behaviour and actions of others. This theory grew from theories about learning processes that take place in society. As found in this study, FRT is influenced by social and cultural factors. Moreover, FRT also is found to be the result of education possessed and psychological factors.

From the findings of this review, investment firms in Malaysia will be able to identify the characteristics of their potential investors. Then, this study will discuss the policy implementation to increase FRT in Malaysia and suggestions on utilisation of FinTech for investment education. By identifying these FRT factors, investment firms will be able to conduct investment education programs that help investors and potential investors with lower FRT to increase their FRT. Hence, this will encourage them to take part effectively in the financial market during the Covid-19 pandemic and Malaysia will be able to achieve economic well-being towards IR 4.0. IR 4.0 is referred to the automation and data 
exchange in manufacturing technologies including the internet of things. In FinTech, IR 4.0 gives an impact on digital innovation and fast financial processes.

\section{REVIEW OF FACTORS INFLUENCING FINANCIAL RISK TOLERANCE}

There are several past studies conducted to examine the factors significant to FRT. The studies explore the factors influencing consumers' FRT in financial decisions and their participation in financial products, such as stocks and retirement plans. The findings obtained are also concluded from studies in Malaysian and other nations' markets for broader perspectives. From the studies below, this study indicates that FRT can be explained by some major categories namely demographic profiles, social and geographical differences, financial capability, and psychological factors. In this paper, these categories will be discussed further for in-depth clarification.

\section{Demographic profiles}

Studies around the world identified the important factors of demographic variables that affect FRT. For instance, Queen and Hassan (2019) measured investment risk tolerance amongst Malaysians to determine the factors affecting their investment risk tolerance for retirement plans. The study proved that factors such as age and income level have a significant correlation with investment risk tolerance for retirement plans. These findings agree with the study by Irandoust (2017) in Sweden. The investigation suggested that educational attainment, income, age, gender, marital status, and family size give impacts on FRT amongst Swedish.

On the other hand, Shah et. al (2020) also concluded income, education, and age significantly affect FRT. The study examined whether these demographic factors explain individuals' FRT amongst Pakistani graduates in business. The study showed that individuals with higher income, older age, and higher education levels have higher FRT. Education is proven to have a crucial role in promoting a sustainable business. Education in business promotes the need for information, communication, and technologies (ICT) and industrial standards setting (Daniel et. al, 2020), while financial literacy in business gives an impact on financial decisions for a business in financial planning and financial market participation. Thus, it will determine the success and sustainability of their future business in today's highly competitive business environment (Razak \& Amin, 2020; Wong et. al, 2020).

In addition, Muktadir-Al-Mukit (2020) analysed the correlation between demographic factors with the level of FRT of stock market investors amongst capital market investors in Bangladesh. In the study, the level of FRT was measured by portfolio beta and reflected by investors' trading behaviour. From the assessment obtained, this study indicated that marital status and family size explain significantly the variety in levels of FRT amongst the stock market investors.

Meanwhile, in the state of Tamilnadu, India, Rajeshkumar and Kasilingam (2017) also investigated the relationship between demographic profiles with FRT amongst investors. This study found significantly strong influences of the demographic variables namely gender, religion, age, occupation, marital status, dependents, number of earning members, and type of family on FRT. Meanwhile, Khan (2017) also proved that investors and employed individuals that are male and have matric or O-level education positively impact FRT. These studies are in line with previous findings where higher education and older age positively impact individuals' FRT. It is believed that higher education and older age provide more knowledge, thinking skills, and experience that support investors' confidence to make a financial decision and take part in the financial markets.

Moreover, Fisher and Yao (2017) revealed gender roles to determine FRT as well. The study emphasised that wealth and income uncertainty are associated with high-risk tolerance differently for men and women. In addition, an investigation by Ferreira and Dickason (2018) suggested that male investors are more risk-tolerant than female investors. The study also indicated that African investors are more risk-tolerant than white, coloured, and Asian investors in South Africa. Findings from the study also proposed FRT differences between male and female investors from different ethnic groups. In this case, white males are found to be risk-takers on above-average risk, as compared to white females who would only take an average risk, or no risk at all. The conclusion proves that local investors in a country are more risktolerant than foreign investors. Therefore, Malaysian investment firms should also consider approaching more Malaysian investors to participate in Malaysian financial markets.

There are also several more studies investigating the influence of gender factors on FRT. For instance, Rolison and (2020) studied gender differences in perceived risk within the risk-return framework. Amongst the domains examined, finance showed lower risk tolerance amongst women, as compared to men. Meanwhile, Hurley and Choudhary (2020) explored the influence of chief financial officers' (CFOs') gender in companies' risk-taking behaviour in the United States. Measurements involved in the investigation are firms' investment in property, plant, and equipment (PPE), debt/ equity ratio, and stock return volatility. In addition, the study also investigated the effect of having female board members in a firm. Findings from the study indicated mixed financial risk from companies with female CFOs, depending on the three risk measures used. However, the risk reduces with the increment of female board members. Companies led by female CFOs also were found to be smaller in size with lower net revenue and net income. Meanwhile, Yakubu (2021) argued that the risk of a firm also can be explained by its dividend payout ratio.

On the other hand, Undale et. al (2021) concluded consistent implication of gender factors on risk tolerance with previous studies. The study investigated the impact of gender and income on comfortability and security concerns to use eWallet in India, amid national lockdown due to the Covid-19 pandemic. The study suggested that female consumers are more risk-intolerant about cyber-crime attacks over eWallet digital payment than male consumers. Consumers from the middle-income group were also found to be more anxious than the respondents from the lower-income group about the security of eWallet financial transactions. Meanwhile, in Iran, Ebrahimi and Sabunchi (2020) examined the influence of 
demographic profiles such as age, gender, education, marital status, income, and job status on the level of risk tolerance amongst stock exchange investors. The prediction from the study is in line with previous findings on gender, where men are found to be more risk-tolerant than women. The study also argued that FRT levels are significantly influenced by age, education, income, and job status. However, the marital status of respondents is found to be insignificant in their risk tolerance in financial decision-making.

In addition, Fan et. al (2020) investigated the roles of gender, political affiliation lines, and income in their differences of risk tolerance, constraints, beliefs, and behaviours during the Covid-19 pandemic amongst adults in the United States. The study indicated that there is a gap in risk tolerance between men and women. Meanwhile, Zeeshan et. al (2021) added to the literature by also examining demographic factors affecting individuals' investment risk tolerance. The study concluded that gender, education, and income positively affect the level of risk tolerance. It was also found that age, work experience, and marital status negatively affect risk tolerance levels amongst individuals' investors. Whereas, Mokoena et. al (2021) explored investors' propensity to take risks in Stokvels (also known as credit unions globally) stock investment. The study analysed the levels of risk tolerance amongst investors based on their demographical variables. Results from the analysis indicate that higher risk tolerance is associated with male, younger, and high-income individual investors.

Factors influencing FRT were also examined by Mohan and Singh (2017). By risk profile analysis, the study concluded that FRT is affected by age, education level, marital status, and a number of dependants. According to the study, FRT is defined by the degree of volatility in returns that investors are willing to tolerate for their investment. In that sense, a study by Niszczota and Białek (2021) found gender effects on investors' judgement towards morally controversial stocks by considering differences in their investment risk tolerance and investment knowledge. The investigation found significantly more tolerance towards controversial stocks amongst men than women. Therefore men are found to be higher tolerant of returns uncertainty than women.

\section{Psychology}

Besides demographic profiles, psychological variables also have been studied around the globe to explore their effects on FRT. Studies such as Rabbani et. al (2020) investigated the influence of sensation seeking and locus of control on FRT in retirement investment portfolio amongst pre-retiree baby boomers in the United States. The study concluded that sensation-seeking determinants positively correlate to FRT. Whereas, external locus of control orientation is found to explain the low level of FRT. In this regard, Naqvi et. al (2020) examined the influences of biopsychosocial indicators, namely sensation seeking, self-esteem, and personality type on FRT. The study concluded that sensation seeking, selfesteem, and personality have influences on FRT significantly amongst retail investors in China. On the other hand, Pinjisakikool (2018) examined the association between cognitive ability and risk as well as uncertainty in decisionmaking. The study concluded the influence of cognitive ability on risk-taking behaviour. This conclusion is in line with the previous studies that proposed higher FRT amongst higher education groups since the optimum cognitive ability is needed to complete higher education.

Meanwhile, Dohmen et. al (2018) explored the big five personality traits as the potential factors that explain differences in FRT amongst households in Netherland. The study found that all of the big five personality traits namely extraversion, agreeableness, conscientiousness, emotional stability, and intellect significantly predict FRT. The big five personality traits were also studied by Chin (2021) to investigate their relation with excess trading of the stock market in Malaysia during the Covid-19 pandemic. The study concluded that personality traits such as agreeableness and openness to experience have significant impacts on investors' trading frequency. In addition, an investigation by Khan (2017) proved that investors and employed individuals with personality traits such as achievement, vigilance, positive and negative emotions in an uncertain environment, explain FRT significantly.

\section{Financial capability}

Moreover, financial capability variables also have been studied around the globe to identify their contributions to FRT. For instance, Muktadir-Al-Mukit (2020) analysed factors that contribute to the level of FRT amongst stock market investors in Bangladesh. From the evaluation carried out, the study indicated that financial responsibility significantly explains the variety in levels of FRT amongst the stock market investors. Whereas, Irandoust (2017) stated that financial literacy and financial stability give impacts on FRT amongst Swedish. In addition, Rajeshkumar and Kasilingam (2017) examined the factors of FRT amongst selected investors' profiles in the state of Tamilnadu, India. In the study, the finding suggested that the amount spent for recreation or entertainment exerts a significantly strong impact on FRT. This finding shows the significance of emotional stability in explaining FRT as suggested by Dohmen et. al (2018) since recreation contributes to one's positive emotion. Meanwhile, studies also proved that higher savings as well as investors and employed individuals that are expecting an inheritance, transfer of assets, or both give impacts on FRT (Shah et. al, 2020; Khan, 2017).

In this regard, Hendrawaty et. al (2020) investigated the influence of financial literacy level on the level of FRT amongst potential investors in Indonesia. The study also examined whether demographic variables such as gender, age, marital status, and income levels moderate the correlation between financial literacy levels and FRT levels. The empirical study concluded that the level of financial literacy does not influence the level of FRT. However, age, gender, and income play significant roles that determine FRT in their investment decision-making. Whereas. Dickason-Koekemoer et. al (2020) examined whether FRT is explained by investors' subjective financial well-being in South Africa. The study revealed that financial well-being, indicated by their state of being financially free and the ability to meet their present 
and future desired standard of living explains different levels of FRT in investment decisions. High financial well-being is associated with high-risk tolerance, indicated by their willingness to invest in high-risk portfolios.

In Chicago, Samanez-Larkin et. al (2020) studied the impact of financial literacy and confidence in financial knowledge on financial risk-taking amongst senior citizens aged 58 to 101, amid vulnerabilities concern around older adult investors. It was revealed from the study that, overconfidence in financial knowledge measurement gives an impact on self-reported FRT positively. Meanwhile, Saputra (2020) indicated that investors' FRT changes with the changes in investment value.

\section{Social}

On the other hand, social variables are found to contribute as well to FRT. In this regard, Beer and Wellman (2021) assessed the impact of perceived stigmatisation and salience of discrimination on FRT amongst gay men in the United States. Findings from this assessment show that higher FRT is associated with individuals with anticipated stigmatisation, after being exposed to information about bias against their community. Moreover, a study by Khan (2017) revealed that cultural dimensions, such as femininity significantly explain FRT amongst investors and employed individuals. Imran and Yusnidah (2019) argued the effect of the cultural aspect on the level of risk avoidance in the stock market amongst Pakistani individual investors. In this regard, Ooi and Chu (2020) supported the connection between culture to finance by emphasising the increment of studies on cultural finance over the last ten years.

Memarista and Puspita (2021) examined the investment risk appetite of young stock investors through their Instagram activities as their social media networking sites. The results suggested that the use of Instagram as a social connection platform and the number of followers on Instagram give impacts on the extroversion personality significantly. This extroversion personality then gives a significant impact on their investment risk appetite. From the finding, it shows that social media and the internet world serve as another dimension in humans' socialisation that gives an impact on their life aspects, including psychology and finance. Therefore, this virtual socialisation deserves serious attention to more examination on its implications.

On the other hand, Chin (2021) studied the underlying psychological and sociological determinants that drive excess trading in the Malaysian stock market during a global health crisis, such as the Covid-19 pandemic. The study utilised investment behaviours to measure their relations with investors' trading frequency. The investigation indicated significant positive impacts of investment behaviours, for instance, years of investment experience as well as the type of investors to trading frequency during the pandemic. In addition, a study by Bellucci et. al (2020) also examined the social crisis impact on FRT. The study analysed the data on conflict events during the Second World War (WW2) and the European Survey on Health, Ageing, and Retirement to examine the significance of variation in war exposure during childhood on adults' FRT. The analysis concluded that adults who were exposed to WW2 during childhood are found to have lower FRT and are less likely to invest in stocks. Experiencing war episodes as kids also decrease their share of stocks held as compared to non-exposed individuals. The findings proved comparable long-term effects of low or high intensity in war exposure on individuals' financial psychology, for instance enhancing uncertainty sensitivity.

Furthermore, Hong et. al (2020) explored the role of FinTech in optimising risk-taking level as the parameter to lower the investment barriers amongst households across cities in China. The study indicated that risk-taking level increases with the FinTech penetration in the Chinese market. Higher risk-tolerant individuals are also found to benefit more from FinTech advancement.

\section{Geographical difference}

In this regard, a geographical factor is also found to have an impact on FRT, but with limited exploration on this variable. For instance, in the highlands of Ethiopia, Ferdinand et. al (2018) indicated higher risk tolerance amongst household heads there as compared to respondents from Western and middle-income countries. Meanwhile, Shah et. al (2020) examined the effect of geographical differences on FRT in Pakistan. The study concluded that different provinces, such as Karachi and Islamabad are found to explain different levels of FRT amongst business graduates. From this indicator, Malaysian investment firms should also consider potential different FRT levels amongst financial market participants from different Malaysian states.

\section{FRAMEWORK FOR FACTORS INFLUENCING FINANCIAL RISK TOLERANCE}

In this study, an extensive literature review on FRT is carried out based on the theoretical framework in Figure 1 below. In this study, FRT is classified as the dependent variable. Meanwhile, the factors that affect FRT are categorised as independent variables. Literature reviews on this subject were obtained from five recent years of studies to ensure the relevancy of this study.

From the studies investigated, the reports obtained from Malaysia and other countries were analysed to identify the factors that determine FRT. 


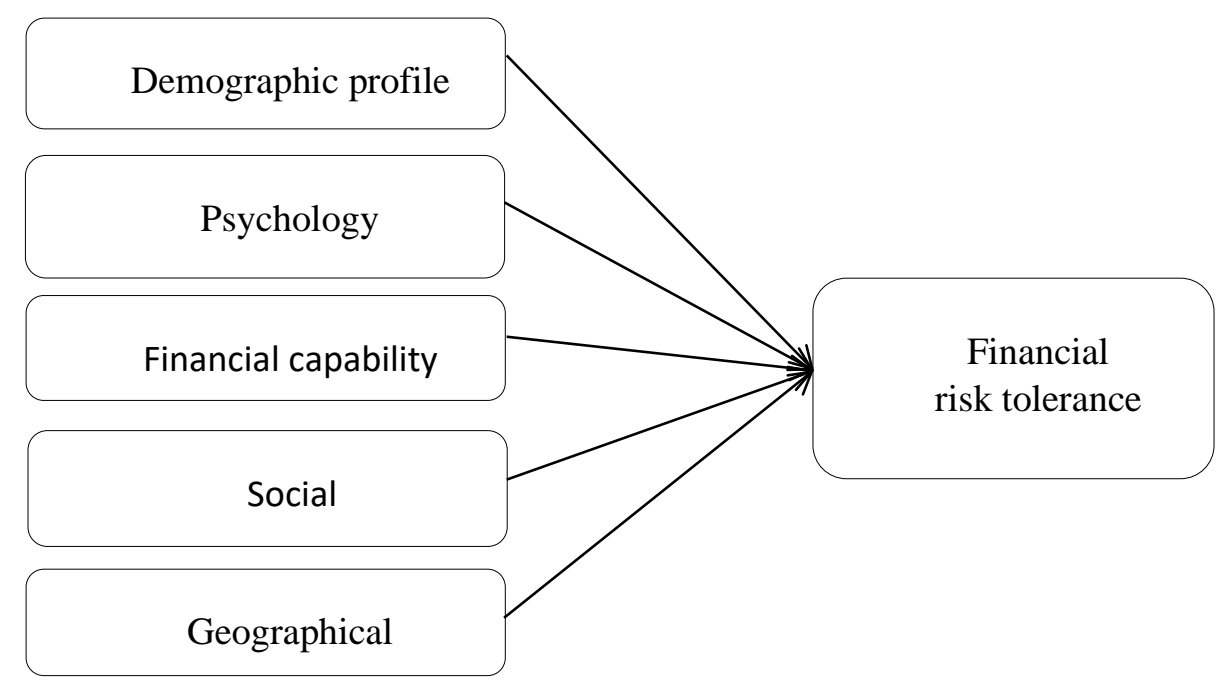

Figure 1. Theoretical framework of factors influencing financial risk tolerance

\section{LITERATURE SUMMARY ON FINDINGS ABOUT FACTORS INFLUENCING FRT}

Findings from this study indicating the factors of FRT are represented in Table 1 below.

Table 1. Literature summary of the factors influencing financial risk tolerance

\begin{tabular}{|c|c|c|}
\hline Factor & Population & Findings \\
\hline \multirow[t]{16}{*}{$\begin{array}{l}\text { Demographic } \\
\text { profile }\end{array}$} & $\begin{array}{l}\text { Malaysia (Queen \& } \\
\text { Hassan, 2019) }\end{array}$ & $\begin{array}{l}\text { Age and income level influence investment } \\
\text { risk tolerance for retirement plans. }\end{array}$ \\
\hline & Sweden (Irandoust, 2017) & $\begin{array}{l}\text { Educational attainment, income, age, gender, } \\
\text { marital status, and family size influence FRT. }\end{array}$ \\
\hline & Pakistan (Shah et. al, 2020) & $\begin{array}{l}\text { Higher income, higher education level, and } \\
\text { older age result in higher FRT. }\end{array}$ \\
\hline & $\begin{array}{l}\text { Bangladesh (Muktadir-Al- } \\
\text { Mukit, 2020) }\end{array}$ & $\begin{array}{l}\text { Marital status and family size explain FRT } \\
\text { for the stock market. }\end{array}$ \\
\hline & Tamilnadu, India & Gender, religion, age, occupation, marital \\
\hline & (Rajeshkumar \& & status, dependents, number of earning \\
\hline & Kasilingam, 2017) & members, and type of family explain FRT. \\
\hline & South Africa (Ferreira \& & Male investors are more risk-tolerant than \\
\hline & & . \\
\hline & & $\begin{array}{l}\text { African investors are more risk-tolerant than } \\
\text { white, coloured, and Asian investors. }\end{array}$ \\
\hline & & $\begin{array}{l}\text { White males are found to be risk-takers more } \\
\text { than white females }\end{array}$ \\
\hline & $\begin{array}{l}\text { United States (Hurley \& } \\
\text { Choudhary, 2020) }\end{array}$ & $\begin{array}{l}\text { Mixed financial risk from companies with } \\
\text { female CFOs. }\end{array}$ \\
\hline & & $\begin{array}{l}\text { Risk reduces with the increment of female } \\
\text { board members. }\end{array}$ \\
\hline & India (Undale et. al, 2021) & $\begin{array}{l}\text { Female consumers are more risk-intolerant } \\
\text { about cyber-crime attacks over eWallet } \\
\text { digital payment than male consumers. }\end{array}$ \\
\hline & & $\begin{array}{l}\text { Middle-income consumers are more anxious } \\
\text { than lower-income groups about the security } \\
\text { of eWallet financial transactions. }\end{array}$ \\
\hline & $\begin{array}{l}\text { Iran (Ebrahimi \& } \\
\text { Sabunchi, 2020) }\end{array}$ & $\begin{array}{l}\text { Male stock exchange investors are more risk- } \\
\text { tolerant than females. }\end{array}$ \\
\hline
\end{tabular}




\begin{tabular}{|c|c|c|}
\hline Factor & Population & Findings \\
\hline \multirow{6}{*}{ Psychology } & $\begin{array}{l}\text { United States (Fan et. al, } \\
\text { 2020) }\end{array}$ & $\begin{array}{l}\text { Gaps in risk tolerance between men and } \\
\text { women during the Covid- } 19 \text { pandemic. }\end{array}$ \\
\hline & $\begin{array}{l}\text { United States (Rabbani et. } \\
\text { al, 2020) }\end{array}$ & $\begin{array}{l}\text { Sensation seeking positively determines } \\
\text { FRT. }\end{array}$ \\
\hline & China (Naqvi et. al, 2020) & $\begin{array}{l}\text { Sensation seeking, self-esteem, and } \\
\text { personality influence retail investors' FRT. }\end{array}$ \\
\hline & $\begin{array}{l}\text { Netherlands (Dohmen et. al, } \\
\text { 2018) }\end{array}$ & $\begin{array}{l}\text { Extraversion, agreeableness, } \\
\text { conscientiousness, emotional stability, and } \\
\text { intellect significantly predict households' } \\
\text { FRT. }\end{array}$ \\
\hline & Malaysia (Chin, 2021) & $\begin{array}{l}\text { Agreeableness and openness to experience } \\
\text { impact stock investors' trading frequency } \\
\text { during the Covid-19 pandemic. }\end{array}$ \\
\hline & Pakistan (Khan, 2017) & $\begin{array}{l}\text { Personality traits namely achievement, } \\
\text { vigilance, positive and negative emotions in } \\
\text { an uncertain environment, explain FRT } \\
\text { amongst investors and employed individuals. }\end{array}$ \\
\hline \multirow[t]{6}{*}{ Financial capability } & $\begin{array}{l}\text { Bangladesh (Muktadir-Al- } \\
\text { Mukit, 2020) } \\
\text { Swedish (Irandoust, 2017) }\end{array}$ & $\begin{array}{l}\text { Financial responsibility explains FRT } \\
\text { amongst the stock market investors. } \\
\text { Financial literacy and financial stability } \\
\text { impact FRT. }\end{array}$ \\
\hline & $\begin{array}{l}\text { Tamilnadu, India } \\
\text { (Rajeshkumar \& } \\
\text { Kasilingam, 2017) }\end{array}$ & $\begin{array}{l}\text { Amount spent for recreation or entertainment } \\
\text { exert impact investors' FRT. }\end{array}$ \\
\hline & $\begin{array}{l}\text { Pakistan (Shah et. al, 2020; } \\
\text { Khan, 2017) }\end{array}$ & $\begin{array}{l}\text { Higher saving as well as investors and } \\
\text { employed individuals that are expecting an } \\
\text { inheritance, transfer of assets, or both impact } \\
\text { FRT. }\end{array}$ \\
\hline & $\begin{array}{l}\text { Indonesia (Hendrawaty et. } \\
\text { al, 2020) }\end{array}$ & $\begin{array}{l}\text { Level of financial literacy does not influent } \\
\text { potential investors' FRT levels. }\end{array}$ \\
\hline & $\begin{array}{l}\text { South Africa (Dickason- } \\
\text { Koekemoer et. al, 2020) }\end{array}$ & $\begin{array}{l}\text { High financial well-being is associated with a } \\
\text { high-risk tolerance. }\end{array}$ \\
\hline & $\begin{array}{l}\text { Chicago (Samanez-Larkin } \\
\text { et. al, 2020) }\end{array}$ & $\begin{array}{l}\text { Overconfidence in financial knowledge } \\
\text { positively impacts self-reported FRT. }\end{array}$ \\
\hline \multirow[t]{6}{*}{ Social } & $\begin{array}{l}\text { United States (Beer \& } \\
\text { Wellman, 2021) }\end{array}$ & $\begin{array}{l}\text { Higher FRT is associated with individuals } \\
\text { with anticipated stigmatisation, after being } \\
\text { exposed to information about bias against } \\
\text { their community. }\end{array}$ \\
\hline & Pakistan (Khan, 2017) & $\begin{array}{l}\text { Cultural dimensions, such as femininity } \\
\text { explain FRT amongst investors and } \\
\text { employed individuals. }\end{array}$ \\
\hline & Malaysian (Chin, 2021) & $\begin{array}{l}\text { Covid-19 pandemic positively impacts } \\
\text { investment behaviours in trading frequency. }\end{array}$ \\
\hline & $\begin{array}{l}\text { Europe (Bellucci et. al, } \\
\text { 2020) }\end{array}$ & $\begin{array}{l}\text { Adults who were exposed to WW2 during } \\
\text { childhood have lower FRT and are less likely } \\
\text { to invest in stocks. }\end{array}$ \\
\hline & & $\begin{array}{l}\text { Experiencing war episodes as kids decrease } \\
\text { their share of stocks held as compared to non- } \\
\text { exposed individuals. }\end{array}$ \\
\hline & $\begin{array}{l}\text { China (Hong et. al, } \\
\text { 2020) }\end{array}$ & $\begin{array}{l}\text { Risk-taking level increases with the FinTech } \\
\text { penetration in the Chinese market. }\end{array}$ \\
\hline \multirow[t]{2}{*}{$\begin{array}{l}\text { Geographical } \\
\text { difference }\end{array}$} & Pakistan (Shah et. al, 2020) & $\begin{array}{l}\text { Different provinces explain different levels of } \\
\text { FRT. }\end{array}$ \\
\hline & $\begin{array}{l}\text { Highlands of Ethiopia } \\
\text { (Ferdinand et. al, 2018) }\end{array}$ & $\begin{array}{l}\text { Household heads in the highlands of Ethiopia } \\
\text { indicate higher risk tolerance than those from } \\
\text { Western and middle-income countries. }\end{array}$ \\
\hline
\end{tabular}


From Table 2 above, FRT is found to be influenced heavily by demographic profiles, then financial capability, social, and psychological factors. Geographical difference has the most limited variable explored as the factor influencing individuals' FRT. According to Mankuroane (2021), demographic factors are significant contributors to the level of risk tolerance investors are willing to accept, which later explains their life satisfaction.

\section{CONCLUSION}

This study has revealed the factors that give an impact on FRT. Therefore, lower financial risk tolerates groups can be identified by investment firms to provide investment education in order to increase the FRT level amongst investors and potential investors. This approach is believed will contribute to avoiding serious mistakes in investment analysis and strategies, elevating investors' and investment firms' performances.

As the findings indicate, FRT is heavily influenced by demographic profiles. Therefore, personal information of investors is a very useful instrument to identify individuals in need of investment education, such as investment workshops. With effective approaches to increasing FRT amongst investors, their financial market participation also will be improved. Hence, Malaysian economic growth can be sustained in the economic survival during the Covid-19 pandemic and to achieve economic well-being towards IR 4.0.

Risk tolerance also has great importance to investment advisors in analysing and measuring the risk-taking ability of their clients to help them choose proper investment products. During a pandemic, investors' investment products choices potentially determine the outcomes for the entire nation, instead of only affecting the investors. Thus, in the near future, researchers may conduct an investigation to identify FRT amongst investors in investment products choices through investment firms. For that purpose, FinTech which is believed to have the potential to enhance financial capability should be applied by smartphone apps utilisation. FRT levels of lower risk tolerance groups can be evaluated by smartphone apps that link to specific investment firms and advisors. Therefore, investment firms play active roles in economic growth and well-being.

Like any other study, this study is also bound to its limitations. Although this study has gathered the evidence literature on factors influencing FRT from many countries across the globe, it is still debatable for future related researches about whether there are other variables that also need to be taken into account. However, to our knowledge, the authors are confident that we have provided the most relevant factors concerning the subject studied. In addition, this study also has discussed a limited number of publications available. The possibility of more studies on factors influencing FRT that are not found is there. Notwithstanding the above limitations, this study believes that it is contributing to the existing literature towards a better understanding of factors influencing FRT.

This study has reviewed the factors influencing FRT. One of the factors influencing FRT identified is geographical difference. However, the study on this factor is still limited. For future study, this study suggests an investigation conducted on the influence of geographical differences on FRT in the investment decision. By this approach, investment firms can consider locating a suitable number of administration offices and employees according to geographical locations for the cost efficiency purpose.

\section{REFERENCES}

Bandura, A. and Walters, R.H.(1977). Social Learning Theory. New York: General Learning Press.

Bannier, C.E. \& Neubert, M. (2016). Gender differences in financial risk taking: The role of financial literacy and risk tolerance. Economics Letters, Volume 145, August, Pages 130-135. DOI: 10.1016/j.econlet.2016.05.033 0165-1765

Beer, F. M. and Wellman, J. D. (2021). Implication of stigmatization on investors financial risk tolerance: The case of gay men. Journal of Behavioral and Experimental Finance,Volume 31, 2021, 100513, ISSN 2214-6350. DOI: 10.1016/j.jbef.2021.100513

Bellucci, D., (2020). Childhood exposure to the Second World War and financial risk taking in adult life. Journal of Economic Psychology, Volume 79, August. DOI: 10.1016/j.joep.2019.102196

Chin, P.N. (2021). What Drives Excess Trading during the COVID-19 Pandemic? Asian Journal of Business and Accounting, Vol. 14, No.1, June. DOI: 10.22452/ajba.vol14no1.5

Daniel, C.J.Y., Wahid, N.A. and Tan, C.L. (2020). WHY SMART LEADERS ARE IMPORTANT IN SMART CITY DEVELOPMENT - A CONCEPTUAL FRAMEWORK. INTERNATIONAL JOURNAL OF INDUSTRIAL MANAGEMENT (IJIM), VOL.5, ISSUE1,1 -9. DOI:https://doi.org/10.15282/ijim.5.0.2020.5617

Dickason-Koekemoer, Z., Myeza, N.S. \& Ferreira, S.J. (2020). The influence of subjective financial well-being on South African risk tolerance. Ife Centre for Psychological Studies/Services, Gender \& Behaviour, Vol. 18 No. 2, June.

Link: https://www.ajol.info/index.php/gab/article/view/198158

Dohmen, T., Armin, F., David, H. \& Uwe, S. (2018). On the Relationship between Cognitive Ability and Risk Preference. Journal of Economic Perspectives, 32 (2): 115-34. DOI: 10.1257/jep.32.2.115

Ebrahimi, S.O.M.H. \& Sabunchi, A. (2020). The Demographical Factors Role in Explanation of Retail Investors' Financial Risk-Tolerance and Their Risk-Taking Behavior. Investment Knowledge, 8(32 ), 217-234.

Link: https://www.sid.ir/en/journal/ViewPaper.aspx?id=811290

Fan, Y., Orhun, A.Y., \& Turjeman, D. (2020). Heterogeneous Actions, Beliefs, Constraints and Risk Tolerance During the COVID-19 Pandemic. National Bureau of Economic Research, May. DOI: 10.3386/w27211 
Ferdinand, M.V., Abebe, B., Randall, B., Sahan, D., Zenebe, G., Peter, M. \& Alemu, M. (2018). Measuring Risk Preferences in Rural Ethiopia. The University of Chicago Press Journals, Economic Development and Cultural Change, Volume 66, Number 3.

Link: https://openknowledge.worldbank.org/handle/10986/21135

Ferreira, S.J \& Dickason, Z. (2018). The effect of gender and ethnicity on financial risk tolerance in South African. African Journals, Gender and Behaviour Vol. 16, No. 1. DOI: doi:10.21511/imfi.15(2).2018.09

Fisher, P.J \& Yao, R. (2017). Gender differences in financial risk tolerance. Journal of Economic Psychology, Volume 61, August, Pages 191-202. DOI: 10.1016/j.joep.2017.03.006

Hendrawaty, E., Nisrul, I. \& Sadalia, I. (2020). Financial literacy, demographic differences and financial risk tolerance level: A case study. Journal of Security and Sustainability, Issues 9 (M). pp. 187-201. DOI: 10.9770/jssi.2020.9.M(15)

Hong, C.Y., Lu, X. \& Pan, J. (2020). FinTech Adoption and Household Risk-Taking. National Bureau of Economic Research, November. DOI: 10.3386/w28063

Hurley, D. \& Choudhary, A. (2020). Role of gender and corporate risk taking. Corporate Governance, Vol. 20 No. 3 , pp. 383-399. DOI: 10.1108/CG-10-2018-0313

Imran, A. \& Yusnidah, I. (2019). UNCERTAINTY AVOIDANCE, RISK AVOIDANCE AND PERCEIVED RISK: A CULTURAL PERSPECTIVE OF INDIVIDUAL INVESTORS. Hasanuddin Economics and Business Review, Vol 3, No.1. DOI: 10.26487/hebr.v3i1.1836

Irandoust, M. (2017). Factors Associated With Financial Risk Tolerance Based on Proportional Odds Model: Evidence From Sweden. Journal of Financial Counseling and Planning, Volume 28, Issue 1. DOI: 10.1891/1052-3073.28.1.155

Khan, S. N. (2017). Financial Risk Tolerance: An Analysis of Investor's Cognitive, Decision-Making Styles and Cultural Effects. Journal of Finance, Accounting and Management, 8(1), 20-38, January.

Link:https://www.proquest.com/openview/1b827b17d5595615a6e204aa23b6d47a/1?pqorigsite $=$ gscholar $\& \mathrm{cbl}=2032035$

Mankuroane, T.E. (2021). Analysing the factors that influence investment intentions in South Africa. North West University (Master Dissertation)

Link: https://repository.nwu.ac.za/bitstream/handle/10394/37041/Mankuroane\%20TE\%2022485546.pdf?sequence=1

Memarista, G. \& Puspita, A. M. A. (2021). Young Investors' Instagram Usage Behavior and Investment Risk Appetite. Management Research and Behaviour Journal, Vol.1, No.1. DOI : 10.29103/mrbj.v1i1.3784

Mohan, R. \& Singh, S. (2017). An Empirical Study on Financial Risk Tolerance of Investors in India. IUP Journal of Financial Risk Management, Sept, Vol. 14 Issue 3, p40-58. 19p. Link: https://ssrn.com/abstract=3218113

Mokoena, K., Dickason-Koekemoer, Z. \& Ferreira-Schenk, S. | Read, R. (Reviewing editor:) (2021) Analysing the risk tolerance levels of stokvel investors. Cogent Social Sciences, 7:1. DOI: 10.1080/23311886.2021.1943890

Muktadir-Al-Mukit, D. (2020). Do sociodemographic factors have influence on risk tolerance level of stock market investors? An analysis from a developing country perspective. South Asian Journal of Business Studies, Vol. aheadof-print No. ahead-of print. DOI: 10.1108/SAJBS-11-2019-0193

Naqvi, M. H. A., Jiang, Y., Miao, M. and Naqvi, M. H. | McMillan, D. (Reviewing editor). (2020). Linking biopsychosocial indicators with financial risk tolerance and satisfaction through macroeconomic literacy: A structural equation modeling approach. Cogent Economics \& Finance, 8:1. DOI: 10.1080/23322039.2020.1730079

New Straits Times (2021). Investors should maintain a well-diversified portfolio, says UOB Malaysia. 29 January.

Link:https://www.nst.com.my/business/2021/01/661520/investors-should-maintain-well-diversified-portfolio-says-uobmalaysia

Białek, M. (2021). Women oppose sin stocks more than men do. Finance Research Letters, Volume 41. DOI:10.1016/j.frl.2020.101803

Ooi, S.G. and Chu, E.Y. (2020). CAPITAL STRUCTURE AND CULTURE IN MALAYSIA: A STUDY FROM ETHNICITY AND RELIGION PERSPECTIVES. INTERNATIONAL JOURNAL OF INDUSTRIAL MANAGEMENT (IJIM), VOL. 8, ISSUE 1, 52 - 61. DOI: https://doi.org/10.15282/ijim.8.0.2020.5763

Pinjisakikool, T. (2018). The Influence of Personality Traits on Households' Financial Risk Tolerance and Financial Behavior. Journal of Interdisciplinary Economics, Volume: 30 issue: 1, page(s): 32-54. DOI: $10.1177 / 0260107917731034$

Queen, C. L \& Hassan, H. H. (2019). The Factors Affecting Malaysian Investment Risk Tolerance for Retirement Plans. International Journal of Innovative Technology and Exploring Engineering (IJITEE), Volume-7 Issue-5S, January.

Link: https://www.ijrte.org/wp-content/uploads/papers/v7i5s/ES2145017519.pdf

Rabbani, A. G., Yao, Z., Wang, C. and Grable, J. E. (2020). Financial Risk Tolerance, Sensation Seeking, and Locus of Control Among Pre-Retiree Baby Boomers. Journal of Financial Counseling and Planning, 32(1):JFCP-18-00072. DOI: $10.1891 /$ JFCP-18-00072

Rajeshkumar, V., and Kasilingam, R. (2017). Does investors' demographics and selected profile factors influence financial risk tolerance? International Journal of Finance, Insurance and Risk Management, 7(1), 1287-1296.

Link:

file:///C:/Users/NETBOOK/Downloads/Does\%20Investors\%E2\%80\%99\%20Demographics\%20and\%20Selected\% 20Profile\%20Factors\%20Influence $\% 20$ Financial\%20Risk\%20Tolerance_.pdf

Razak, D.A. and Amin, H. (2020). THE EFFECTS OF FINANCIAL KNOWLEDGE, SOCIALISATION, ATTITUDE AND SKILL ON MALAYSIAN SMES' PERFORMANCE. INTERNATIONAL JOURNAL OF INDUSTRIAL MANAGEMENT (IJIM), VOL. 8, ISSUE 1, 1 - 11. DOI: https://doi.org/10.15282/ijim.8.0.2020.5758 
Rolison, J.J. \& , J. (2020). How much risk can you stomach? Individual differences in the tolerance of perceived risk across gender and risk domain. Journal of Behavioral Decision Making, Volume33, Issue1, Pages 63-85. DOI: $10.1002 / \mathrm{bdm} .2144$

Samanez-Larkin, G. R., Mottola, G., Heflin, D., Yu, L., \& Boyle, P. (2020). Overconfidence in financial knowledge associated with financial risk tolerance in older adults. Center for Cognitive Neuroscience, Duke University, Durham. DOI: $10.31234 /$ osf.io/p5gec

Saputra, J. (2020). Some Forms of Investor Risk Tolerance in Investing: Review Theory International Journal of Research in Community Services, Vol 1, No 3. DOI: 10.46336/ijrcs.v1i3.105

Shah,N. H., Khalid, W., Khan, S., Arif, M. and Khan, M. A. (2020). An Empirical Analysis of Financial Risk Tolerance and Demographic Factors of Business Graduates in Pakistan. International Journal of Economics and Financial Issues, 2020, 10(4), 220-234. DOI: 10.32479/ijefi.9365

Undale, S., Kulkarni, A. \& Patil, H. (2021). Perceived eWallet security: impact of COVID-19 pandemic. Vilakshan XIMB Journal of Management, Vol. 18 No. 1, pp. 89-104. DOI: 10.1108/XJM-07-2020-0022

Wong, C.T., Tan, C.L. and Mahmud, I. (2020). BUSINESS INTELLIGENCE SYSTEM ADOPTION: A SYSTEMATIC LITERATURE REVIEW OF TWO DECADES. INTERNATIONAL JOURNAL OF INDUSTRIAL MANAGEMENT (IJIM), VOL.6, ISSUE1,1 -8. DOI: https://doi.org/10.15282/ijim.6.0.2020.5624

Yakubu, I.N. (2021). The Effect of Working Capital Management on Dividend Policy: An Empirical Analysis of Listed Firms in Ghana. INTERNATIONAL JOURNAL OF INDUSTRIAL MANAGEMENT (IJIM), VOL. 9, ISSUE 1, 25 - 31. DOI: https://doi.org/10.15282/ijim.9.0.2021.5952

Zeeshan, A., Sattar, A., Babar, S., Iqbal, T. and Basit, A. (2021). Impact of Demographic Factors on Investment Risk Tolerance. IJBEA, Vol.6, No.2 DOI: 10.24088/IJBEA-2021-62004

\section{CONFLICT OF INTEREST}

The authors, as noted, certify that they have NO affiliations with or involvement in any organisation or agency with any financial interest (such as honoraria; educational grants; participation in speakers' bureaus; membership, jobs, consultancies, stock ownership, or other equity interest; and expert testimony or patent-licensing arrangements), or nonfinancial interest (such as personal or professional relationships, affiliations, expertise or beliefs) in the subject matter or materials addressed in this manuscript. 


\section{AUTHORS' BIOGRAPHY}

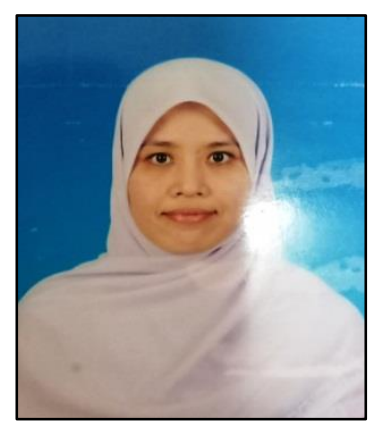

Author's Full Name: Mubarokah binti Bunyamin Author's Email: mubarokah2020@hotmail.com Author Professional Bio:

Mubarokah binti Bunyamin is currently a doctoral candidate in Faculty of Industrial Management, University Malaysia Pahang. She obtained her degree in Master of Science (Financial Mathematics) from University Science Islam Malaysia in 2018. In 2012, she obtained degree in Bachelor of Science (Mathematics) with Education from Universiti Pendidikan Sultan Idris, Malaysia. She experienced as administrator and human resource administrator in few private companies. In 2020, she joined Tamhidi (Foundation Studies) Centre, University Science Islam Malaysia as part time Mathematics tutor before enrolling in doctoral studies.

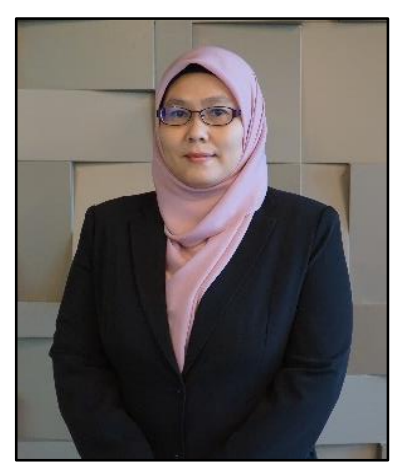

Author's Full Name: Norwazli Bt Abdul Wahab Author's Email: norwazli@ump.edu.my

Author Professional Bio:

Norwazli Bt Abdul Wahab is currently a Senior Lecturer at Faculty of Industrial Management, Universiti Malaysia Pahang (UMP). She obtained her PhD from Universiti Teknologi MARA (UiTM). She completed her Master of Business Administration in Finance, Bachelor of Accountancy (Hons) and Diploma in Accountancy from Universiti Teknologi MARA (UiTM). She has experience working in the industry as an account and finance executive. Her areas of research include corporate governance, corporate social responsibility, corporate financial performance, financial planning and risk management. 